\title{
Learning Organization Attributes and Performance of G4s Kenya Limited Mombasa County, Kenya
}

\author{
Diana B. A Otieno ${ }^{1}$, Dr. James Maina² \\ ${ }^{1}$ Correspondent Author, Master of Business Administration (Strategic Management), \\ Kenyatta University, Kenya \\ ${ }^{2}$ Lecturer, Business Administration Department, School of Business, Kenya
}

\begin{abstract}
Learning organization refers to an organization that encourages its individuals to learn and consistently change its form. Organizations give both formal and casual procedures and structures for securing, sharing and utilization of information and abilities. Learning organizations come about due to pressures that are faced in the modern time organizations and vest these organizations to retain their aggressiveness in the business world. The learning organization urges organizations to move to a more interconnected mindset. Organizations ought to wind up more like networks that workers and its members can feel a responsibility towards them. The site of the investigation was at G4S Kenya Limited in Mombasa County. The specific objective was to determine the consequences of learning organization on the execution of G4S Kenya limited. The study was then guided by the following objectives; to find out the impact of systems thinking on performance of an organization, to determine how personal mastery affects the performance of an organization, to examine the influences of mental models on performance of an organization as well as to research on the impact of shared vision on performance of an organization. The study was guided by Argyris and Schön's Theory and Systems Theory. The investigation was carried out on 150 representatives from G4S Kenya Limited. An adjusted Likert scale questionnaire separated into three (3) sections was created. A pilot study was done to fine-tune the instrument. Information gathered was reviewed on a PC by use of Statistical Package for Social Science (SPSS Version 22) for Windows. The collected data was then examined using statistical methods of frequencies and percentages, with the aid of MS Excel. Charts, tables and bar graphs were then used to present the information. The summary of the main component of the study conclusion was based upon the research objectives. The researcher deduced that a system thinking provides continuous learning opportunities in the organization; embraces creative tension as a source of energy and renewal, link individual performance with organizational performance. This is because the majority of the respondents indicated that system thinking link individual performance with organizational performance. This component scored highly on the adjusted Likert scale; a clear indication of the importance of system thinking on the performance of G4S Kenya Limited. The investigation on the influences of learning organization on the performance of G4S Kenya limited was recommended for further study since it has brought to light the effect of systems thinking, personal mastery, and mental models and shared vision on organization performance.
\end{abstract}

Keywords: Learning Organization Attributes, Organization Performance, G4s Kenya Limited

DOI: 10.7176/ijcab.v3iIII.41, URN: nbn: de:0000ijcab.v3iIII.415 


\section{Cite this Article:}

Otieno, D., \& Maina, J. (2019). Learning Organization Attributes and Performance of G4s Kenya Limited Mombasa County, Kenya. International Journal of Current Aspects, 3(III), 212-226. http://journals.ijcab.org/journals/index.php/ijcab/article/view/41

\section{INTRODUCTION}

The learning organization is a fantasy of what might be possible. It is not accomplished just through teaching individuals, yet it can simply happen in view of learning at the entire affiliation level. Learning organization is an affiliation which energizes learning for all its people and continually changes its form, (Adler et al. 2016). Learning affiliations are depicted by entire specialist commitment in a strategy of agreeably driven, inside and out dependable change facilitated towards shared characteristics or gauges, (Argyris, 2015). A learning affiliation hopes to shape its future. It is one that recognizes learning as an inventive and progressive course for its individuals and, builds and transforms its form due to the needs and wants of people, inside and outside its form, (Navran Associates Newsletter, 2013). Learning organization refers to an affiliation that supports its people to learn and steadily changes its form. Learning organizations come about due to pressures arising in current firms and allows them to stay centered in the dynamic business condition. The learning organization thought was founded through Peter Senge and his accomplices' work. It urges firms to migrate to better-interrelated perspective. Organizations should end up just as systems that representatives and its people can feel a commitment, (Rheem, 2015).

According to Rheem (2015), learning affiliations develop a space where its people can create the outcome they actually need, and where they can make sense of learning as a team for the progression of the aggregate. The articulation "learning organization," not to be mistaken for "organizational learning," was advanced by Peter Senge. It portrays a relationship with a perfect learning condition. Such an organization is the place individuals reliably create their capability to attain the outcomes they actually need, where original and broad precedents of rationale are supported, where absolute desire is enlarged, and where individuals are perseveringly making sense of seeing the whole (reality) together, (Senge, 2016). Learning associations are those that have set up frameworks, instruments and, procedures, that are utilized to constantly upgrade their capacities and the individuals who work with it or for it, to accomplish economic destinations for themselves and the networks in which they partake. Firms learn from people who learn. Singular learning does not assure hierarchical learning. Few authoritative pioneers are perceiving the radical re-examining of corporate theory which a pledge to singular learning requires. Kazuo Inamori, founding father and leader of Kyocera (a world pioneer in cutting edge earthenware production and innovation utilized in electronic parts, medicinal materials, and its very own line of office robotization and correspondences hardware), says this: Whether it is innovative work, organization administration, or some other part of business, the dynamic power is "human resource." And individuals have their very own will, their own brain, and their own particular manner of reasoning, (Garvin, 2014). On the off chance that the workers themselves are not adequately persuaded to test the objectives of development and mechanical improvement, there will be no development, no gain in profitability and no innovative advancement.

Tapping the capability of individuals, Inamori accepts, will require another comprehension of the "subliminal personality," "resolve," and "activity of the heart . . . true want to serve the world." He trains Kyocera workers to search internally as they constantly make progress toward the ideal guided by the corporate rule, "Respect Heaven and Love People." In turn, he trusts that his obligation as a supervisor begins by accommodating both the material and inner welfare of his representatives. A world apart, in an entirely separate industry, Bill O'Brien, 
leader of Hanover Insurance, attempts at hierarchical models that are more harmonious with human instinct, (Gephart, 2016). Just as Inamori, O'Brien claims that supervisors must rethink their task and furthermore, that they should surrender the old authoritative opinion of arranging, sorting out and controlling and, understand the dedication of their duty regarding the lives of such huge numbers of individuals. Howe (2012) consolidating to make life more difficult at any other time for set up organizations to get by in a universe of severe rivalry. Such an aggressive domain is described by intermittence and vulnerability that is best obliged by associations that have the ability to learn and adjust quicker than their rivals. These organizations are known as learning associations and are exemplified by the nearness of insightful authority, adaptable structures and engaged community-oriented people, (Liker, 2014). Be that as it may, is being a learning association adequate in its own entitlement to empower an organization to contend effectively? A developing topic in the administration publications in the course of the last 10-15 years has been the acknowledgment of associations and systems as fundamental parts of an organization's focused technique, (Swann et al., 2015).

As shown by Senge (2010), learning organizations are affiliations whereby individuals repetitively stretch out their capabilities to obtain the outcomes they actually need; whereby emerging and extensive precedents of rationale are supported; whereby absolute desire is enlarged; and whereby individuals are perpetually creating a sense of seeing the whole together. The fundamental reason for alike affiliations is, in conditions for quick transformation, only those that are versatile, productive and flexible will reign. In order for this to happen, it is declared, affiliations have to find out a way to draw an individual's devotion and ability to learning at every level. Although everyone has the potential to be taught, the arrangements that they have to work on are habitually not accommodating for reflection and duty. In addition, people may not have the instruments and guiding plans to comprehend the conditions that confront them. Affiliations that are reliably developing their ability to influence their future to call for a focal move on perception amongst its people. When you get some data on what it feels like to be a section of a fantastic gathering, what is most notable is the significance of the experience. People speak of being a section of a choice that is greater than themselves; of being related; of being generative. It ends up being exceptionally clear that, for a few, their experiences as an element of extremely mindblowing cluster project as single occasions of a real presence lived without restrictions. Some people use the remainder of their lives hunting down methods to get back to that spirit (Senge, 2010).

Senge (2010) characterized a 'learning organization' as a dynamical framework that is in a condition of consistent adjustment and enhancement. Learning organizations construct criticism circles intended to augment the viability of their learning forms. Instrument of building Learning Organization: Any affiliation that requires to end up as a learning organization should do as follows: Produce and impart a common vision for the firm, create documentation in the firm reachable to everyone, enable representatives to oversee transformation by foreseeing variation and making the sorts of progress required by the firm, enable workers to act, recognize and reinforce the necessity to take chances and learning to deal with the firm's learning by: maintaining current material, keeping up recorded learning, tending to expanding volumes of data, set up and utilize individual and organizational learning procedures and estimation of learning organization, (Fossum, 2016). The following are applied to evaluate learning organization: a holistic setting which incorporates systems thinking, for the most part seeing interconnections and designs among key factors and precise critical thinking. Strategic push which incorporates sorting out things to be done, understanding their outcomes, organizing the work and sharing strategies at all levels. Shared 
vision which incorporates building up a dream which joins with individual objectives, conveying the vision and creating and utilizing transformational authority, equipping: which incorporates decentralization, transference, devolution, trust, offering help when required and remunerating activity and choices (Cohen and Klepper, 1996). Data stream: which incorporates free stream of data at all levels, limited speculation and advocate for inside trade of thoughts, Internality: which incorporates embodiment of power over most piece of our predetermination, good faith, self-restraint, responsibility and moderate hazard taking, learning: which incorporates a few instrument and sources which are of great importance and empowering self-improvement, making favorable atmosphere for learning and empowering and making use of conversation and dialogs and cooperative energy: which incorporates joint effort and collaboration, compassion, thinking together, negotiations, composed activities and utilizing cross-utilitarian groups, (Howe, 2012).

Mahapatro (2010) described the organizational performance as the limit of an organization to attain its primary objective through a sound organization, strong organization and a resolute rededication to obtaining results. Effective philanthropies are mission-driven, flexible, customer based, venturesome, result driven and empirical. Organizational execution is used to determine the practicality and viability of the organization. Corporate implementation incorporates the basic activities to develop organizational objectives, keep track of advancement toward the targets, and roll out improvements to achieve those objectives in a manner that is well organized and productive. Determination of organizational performance: The different guidelines applied in our research are; supply, client, worker, responsibility, the procedure of upgrading Organizational Performance and distinguishing the procedure stream. This is the first and maybe most essential move. On the off chance that the representatives cannot concur on their procedure, by what means can they viably gauge them or use the yield of what they have estimated? Distinguish the basic movement to be estimated. The basic action is that coming full circle movement where it bodes well to find a sensor and characterize an individual execution measure inside a procedure and build up execution goal(s) or models. All execution measures ought to be fixing to a predefined objective or standard, regardless of whether the objective is at first to some degree abstract. Having objectives and benchmarks is the best way to seriously translate the consequences of your estimations and check the achievement of your administration frameworks.

Set up execution measurement(s); in this progression, keep on building the execution estimation framework by distinguishing singular measures and recognize dependable party(s). A particular substance (as in a group or an individual) should be allocated the duties regarding every one of the means in the execution estimation process. Gather information notwithstanding recording the numbers; the information should be pre-investigated in an opportune manner to watch any early patterns and affirm the suitability of your information accumulation framework (Ogiji \& Ejembi, 2007). Evaluate/detail real execution; in this progression, the crude information is formally changed over into execution measures, showed in a justifiable frame, and dispersed as a report. Differentiate real execution with a goal(s); in this progression, look at execution, as introduced in the answer, to fore-established objectives or principles and decide the discrepancy (assuming any). Contingent upon the extent of the discrepancy among estimations and objectives, some type of remedial activity might be called for. Roll out improvements to align back with the objective. This progression just happens if remedial activity is presumed to be vital. The establishment of the remedial activity is a piece of the quality enhancement process, not the execution determination process. This progression is essentially worried about the enhancement of the administration framework. Indeed, even in effective frameworks, changes may be amended with the end goal to set up ones that challenge an organization's assets; however, don't overburden them. 
Objectives and measures require an occasional assessment to stay aware of the most recent organizational procedures.

G4S Kenya Limited is the world's dominant international security solutions supplier majoring in subcontracting of business in areas where security risks are viewed as a strategic threat. G4S Kenya is a member of the G4S group that has its Headquarters in London. The organization at present works in more than 125 nations universally and hires more than 650,000 individuals making it the second biggest private division leader on the planet. G4S Kenya Limited is a branch of G4S PLC recorded in the London stock trade and Copenhagen stock trade. (http//www.g4s.ke.org). G4S Kenya Limited was set up on September 25th, 1963 as a Night security organization. In September 25th, 1969 the organization altered its name to Securicor Security Service Kenya Limited. The organization rebranded on September nineteenth, 1997 to Securicor Security Kenya Limited offering the manned security and courier administration. On fourteenth February 2006, the organization rebranded and altered its name to G4S Security Services Kenya Limited. This prompted a debate with one of its nearby rivals, Group 4 security services on the name and the issue had been brought before the courts. In 2008, the court decided that Group 4 security services retain the name and therefore, the organization changed its name on sixteenth September 2011 to G4S Kenya Limited.

In Kenya, G4S has more than 15,000 workers at various industries such as commercial, accommodation, training, government, consulates, UN organizations, and mining among others. G4S Kenya has diverse specialty units that are composed of various executives and utilitarian administrators. These specialty units are Electronic Security Services (ESS), Cash Solutions Services (CSS), Secure Logistics Solutions (SLS), Secure Data Solutions (SDS) and Manned Security Services (MSS). G4S takes pride in offering clients creative arrangements through the utilization of nearby market learning developed after some time and enhanced by worldwide mastery. The organization offers a far-reaching scope of security arrangements. G4S Kenya Limited offers a total suite of administrations to give a complete security arrangements intended to address client's issues including cash-in-transit business, manned security, front office administration, emergency response services, CCTV, access and egress control, information achieving, transport, Logistics, event administration, vehicle asset tracking, and fire administrations.

Supported by the best individuals in the industry and the most recent innovation, G4S conveys premium administrations with aggregate quality and total honesty. A portion of the key accomplishments of G4S incorporates however not constrained to the arrangement of access control to the Pentagon in the US, occasion administration on the world cup and presentation of bulletproof vehicles for cash-in-transit business. G4S Kenya Limited boasted of over $80 \%$ market share in the industry in the most recent decade. At present, this is reported to be declining as has been the organization's profit. G4S provides services to private establishments and private premises as well. In addition, G4S offers cash-in-transit business thus the need to constantly improve on their methods of transporting money through enhanced innovation. An increment in client inclinations and taste, rivalry, and the financial conditions have added to the requirement for transformation in the organization. The administration group of $\mathrm{G} 4 \mathrm{~S}$ is qualified for dealing with the incorporation of the organization and their customers in a way that the workers and the customers will grasp the transformation by assuming the job of facilitators and empowering agents of progress.

\section{STATEMENT OF THE PROBLEM}

Organizations give both formal and casual procedures and structures for securing, sharing and utilization of information and abilities. Learning is never again viewed exclusively as a 
classroom movement. It is important to empower workers to wind up more capable at a specific assignment by concentrating more on the learning introduction of an organization. Also, more assets ought to be put on encouraging conditions, for example, correspondence stage and preparing programs for advancing organizational learning. Accordingly, organizations are endeavoring to make more open doors for consistent worker learning, for example, through collaboration, strengthening, and more extensive occupation structures and plan, (Napier et al., 2015). These contentions suggest that learning organization is getting more essential particularly when data frameworks/innovations bring more business openings and prompt more serious rivalry. With the end goal to all the more likely meets the fast changes in innovation and the business condition, learning is progressively observed basically as a nonstop work-based movement for information as a wellspring of significant worth, powerful commercial center, expanding rivalry, more noteworthy client requests, and effortlessly imitable items/forms. In this way, representatives need to learn rapidly with the end goal to empower the organization to support its intensity, (Zuber, 2012). This will enable these people to distinguish creative methods for working and make it less demanding to receive new innovation, which thus allows the organization to separate from its rivals.

The failure to care for the learning of gatherings and persons in the firms brings catastrophe to this specific circumstance. Larson, (2016) shows that firms require to not only put in new hardware to increase the proficiency of generations but also in the stream of expertise that can support their trade. Firms should excel in information age, allocation, and exploitation. The information that is obvious will, in general, be unequivocal, open to instruction, free, separable also simple for contenders to impersonate. Then again, the learning that is impalpable, implicit, less assertive, less detectable, is more perplexing however difficult it is to isolate from the individual who made it or the setting in which it is implanted. Information conveyed by a party just understands its business prospective when it is reproduced by a firm and winds up organizational learning. The researcher chose to undertake studies in G4S since the organization is a worldwide organization which has specialty units which will assist the researcher when addressing diverse difficulties that the organization experiences amid the transformational procedure. Representatives at G4S do not have submissive participants in this specific situation; they identify methods of portraying rational and testing their individual capability to give more value to a superior workstation by taking an interest in transformation of perception from the conservative rule of operational setting reasoning to one whereby the chain of command is detached, and personal capability is declared. Learning organizations at G4S supports a situation whereby people "form outcomes they really wish for," and where they can discover how to collectively learn for the advancement of the entire organization.

G4S as an affiliation has experienced distinctive transformation through re-engineering, mergers, and acquisitions. While a number of examinations have been adopted on learning organization in communities and private areas, little has been done on the impacts of learning organization on performance in an international affiliation with various specialty units. For example, the research by Mute (2016) concentrated on overseeing change in the water segment. Other people who have attempted investigations on learning organization in different enterprises comprised of Muhia (2014), whose review concentrated on the effects of system thinking, and Oganda (2017), whose research concentrated on the impacts of a shared vision to organization development at Wrigley Co East Africa. Notwithstanding, the way that learning organization is quickly picking up acknowledgment in Kenya does not certainly imply enhanced organization execution. Based on the analyst' information, there is restricted exact proof on the impacts of learning organization on execution in Kenya. This investigation tried to address the prevailing investigation gap by giving feedback on the following investigation questions: Do systems thinking affect organization performance? Does personal 
mastery affect organization performance? Do mental models affect organization performance? And finally, does shared vision affect organization performance?

\section{OBJECTIVES OF THE STUDY}

The overall objective of the investigation was to determine the consequences of learning organization on the execution of G4S Kenya limited. The explicit objectives of the investigation included;

i. To investigate the influence of systems thinking on the performance of G4S Kenya Limited.

ii. To establish how personal mastery affect the performance of G4S Kenya Limited.

iii. To discover how mental models affect the performance of G4S Kenya Limited.

iv. To find out how shared vision affects the performance of G4S Kenya Limited.

\section{THEORETICAL FRAMEWORK}

A broad survey on the writings on the administration of progress and learning organization (Blake, 2016) demonstrated that effective transformational change relies upon the initiative of the organization introducing unquestionable proof for the need to change and articulating a dream for the eventual fate of the organization that is sensible, sound, alluring and predictable with the center estimations of the organization on the off chance that they are to pick up the dedication of representatives to the change procedure. Pioneers exhibit that they experience the change vision by setting up an organizational situation that engages the individual, advances coordinated effort, offers help, has a predisposition for an appearance in real life and energizes transparent correspondence. Such a domain is the establishment on which a learning organization is constructed (Bales, 2014) and the way toward changing an organization into a learning organization includes three particular stages that are focused on taught individuals being occupied with trained idea and undertaking restrained activity to build up an organization's center skills - its abilities to work together, learn, assimilate and execute, that empower enhanced aggressive execution, (Carnall, 2010).

In view of these bits of knowledge from the writing, a model of an organization that sustains learning-authority that is comprehensive, steady and proactive; a culture of individual duty and group responsibility; and an organizational structure that advances coordinated effort and open correspondence; and empowers the improvement of the abilities to produce and apply new information successfully - the nearness of a mutual vision, responsibility, and the aptitudes to take an interest, can be developed. Thus, the survey of the writing relating to inter-agencies associations demonstrated that the sorts of connections that exist between store network accomplices are fluctuated and go over a range from value-based through agreeable/composed to the collective (Baumeister, 2012). More community-oriented connections are based on trust and responsibility and require the nearness of a common vision alongside a venture of time, assets and administrative aptitude on the off chance that they are to be set up and looked after, (Gerger, 2014). More shared connections likewise enable individual organizations and the association to enhance access to data and develop more chances for adaptability, advancement, and learning, (Carey, 2015). These bits of knowledge on store network connections and their administration were consolidated with the model of a learning organization to make a model of organizational learning with regards to a production network that represents the collaboration between organizational connections and the exchange of information.

\subsection{Systems Theory}

Systemic thinking is the sensible establishment of Peter Senge's strategy. It is the science which incorporates all and merges all into a sound array of speculation and practice, (Senge, 
2010). Systems speculation's capacity to understand and convey the entire and to break down the internal relationship among the departments suits Peter Senge, the driving force and the best approach to organize the controls. There are three things that require mentioning here; firstly, systems speculation scans for affiliations and the total. In such manner, it empowers people to look past the speedy setting and to welcome the influence of their exercises on others (and conversely). To this degree, it bears the probability of realizing a comprehensive insight. Secondly, though the building squares of systems theory are essential, they can consolidate with a preferably further developed model over that that is obtainable in countless organizations (Garvin, 2014). Senge acknowledges that one of the primary issues which a lot is discussed on, and acted upon with the aim of improved administration, is that to some degree silly structures are associated with the eccentric systems. If these two points are incorporated, it is likely to advance past an accentuation on the parts, and start to view the whole along these lines, recognizing the organization as a dynamic system. The conflicting view runs a predominant valuation for systems, therefore, inciting more legitimate deed.

Thirdly, systems thinking as demonstrated by Senge empower us to comprehend the centrality of response instruments in firms. He presumes that the structures viewpoint is orchestrated toward the whole deal. That is why deferrals and feedback circles are so imperative. For the present, one can routinely ignore them thinking that they are irrelevant only for them to cause issues not far off for you in future, (Senge, 2010). Systemic thinking empowers the organization to comprehend the enormity of information instruments in the organization making more utilitarian and enhancing coordination. While the major mechanical assemblies of structures theory are really immediate, they can combine with refined models. Peter Senge fights that one of the primary matters which is greatly discussed, and acted upon with the aim of achieving the purpose of the organization, is that to some silly degree, structures are related with the astounding systems. Focus will, therefore, be on the parts instead of seeing the whole, and disregard seeing the organization as a vibrant strategy. In this way, the dispute runs a prevalent vitality about systems will provoke all the more appropriate movement. 'We gain more from personal experience, despite not particularly experiencing the consequences of an extensive allotment of our most fundamental choices', Peter Senge (2010) states as to organizations. We are inclined to believe that when all is said in done, conditions and final products will be respectably near one another. In this way when confronted with an issue related to execution, the 'courses of action' that are close by to that are considered. Customarily, we adopt exercises that organization like G4S Kenya Limited can conduct to upgrade results in a decently short time period. Regardless, when looked at in systems terms, without a moment's hesitation upgrades consistently costs the organization a great deal. Some part of the issue the organization stands up to is the possibility of the information the organization gets. A segment of the feedback will invigorate with little changes developing themselves.

\subsection{Argyris and Schön's Theory}

The main advocators of organizational learning theory are Argrys and Schon (2016). Organizational learning (OL), as demonstrated by Argyris and Schon is an after-effect on the demand of a firm. This dictates that at any point anticipations shifts from the genuine outcome, an individual (or an organization) will take an interest in demand to understand and, if crucial, light up this specific anomaly. Within the time spent on organizational demand, the individual will relate with different people from the firm and learning will occur. Learning is, thus, a quick consequence of this joint effort. Argyris and Schon push that this collaboration habitually surpasses the portrayed firm rules and philosophy (Schutz, 2016). Every organization will, when all is said in done, have distinctive rules concerning the way in which laborers should act with the true objective to do their occupations (e.g., basic thinking). These 
rules are every now and again specific and constrained in pack thus limiting an individual to a pre-determined way. An instance of maintained speculation could possibly be "if the PC does not work, try restarting it and after that get in touch with IT division."

The path that there exists a disparity between these two systems is hypothetically precarious if the organization maintains its espoused philosophy. With the ultimate objective to make an area supportive for learning, firms are encouraged to recognize speculation being utilized and make it basic for the individual to relate with his work environment in an unlimited and unstructured way. Fundamentally they should give the right condition to the organizational demand to happen without being limited by formal systems, (Howe, 2012). Levy, (2016) broadened the support on the components of organizational learning theory. His ideas show the firm as ordinary inclined, history contingent, and target focused. While practices from the past are secured in the memory of the firm, the event itself is as often as possible lost. He observes that past activities are gotten by plans for a method which makes the activities, anyway not the previous records, open to firms and its people. The challenges organization go up against is that it is commonly better to have the event instead of the explanation. Organization learning is spread through socialization, knowledge sharing, simulation among others, and might be altered after a period of time due to understandings of the past.

Argrys and Schon (2012) recognize three stages of learning which are accessible by the organization, for instance, G4S Kenya Limited. The first is the Single circle learning which includes one information circle and when the philosophy is changed in light of a startling result (oversight review). For example, at the point when business (execution) decline in an organization, managers look into the reason for this and modify the strategy to endeavor to bring business back on track. The second is the Double circle learning which is learning that results in a modification on a basic level being utilized. The characteristics, procedures, and suppositions that direct action are changed to make a more capable condition. As from above model, organization administrators may reconsider the entire process so that there will be no (or less) such instabilities later on and the third is Deutero learning where learning is tied in with upgrading the learning system itself. This is made out of assistant and lead sections which choose how learning occurs. Basically, deuteron learning is, more like "learning how to learn." This might be solidly associated with Senge's idea on the learning organization, predominantly as for refining learning strategies and perception/changing mental models. Suitable learning must, along these lines, join all of the three, continually upgrading the firm's execution at all stages. Regardless, while any firm will use single circle learning, double circle and preferably deuteron learning, is an unquestionably significant test, (Kaplan, 2016). This speculation is extraordinarily principal in the examination since it urges the organization to conform to changes when the execution of the organization decreases. It helps the agents and organization in learning which transmitted through socialization, knowledge sharing, and simulation and so on, and can change after some time in view of interpretations of history.

\subsection{Resource-Based View Theory}

The resource-based view (RBV) of Wernerfelt (1984) suggests that strategy implementation can be achieved by innovatively delivering superior value to customers. The extant literature focuses on the strategic identification and use of resources by a firm for developing a sustained competitive advantage (Barney, 1991). International business theorists also explain the success and failures of firms across boundaries by considering the implementation of their subsidiaries or local alliances in emerging markets (Luo, 2003). Local knowledge provided by a subsidiary or local alliance becomes an important resource for conceptualizing value as per the local requirements (Gupta et al., 2011). In learning organization attributes, RBV 
theory has emerged as one of the theoretical perspectives used to explain persistency in inter-firm performance differences (Barney and Griffin, 1992). According to RBV theory, firms have collections of unique resources and capabilities that are valuable, rare, inimitable and non-substitutable and which are able to provide them with a sustainable competitive advantage. Hence, resources are tangible and intangible assets that are either owned or controlled by a firm, whereas capabilities refer to its ability to exploit and combine resources through organizational routines in order to achieve its objectives (Amabile et al, 2016). For this study, by applying RBV theory, it is important to investigate how internal and external resources can be influenced by learning organization attributes and enable an organization's capabilities to enhance performance (Galbreath 2005).

\section{CONCEPTUAL FRAMEWORK}

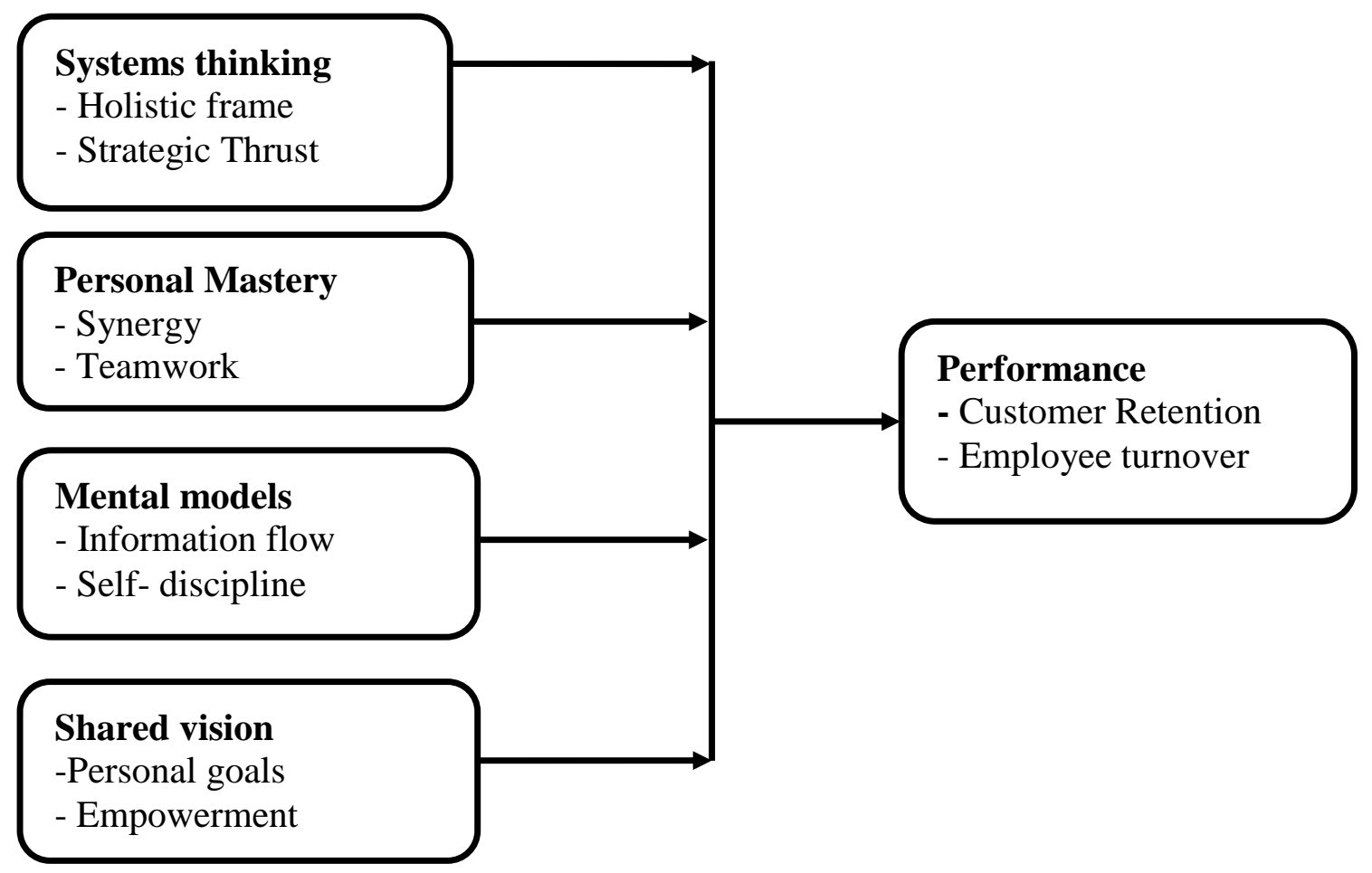

Figure 1: Conceptual Framework

\section{RESEARCH METHODOLOGY}

A research design refers to the approach used to conduct a study right from the data collection process to the analysis and presentation of findings. Examples of research designs include explorative and descriptive research design. The proposed research used a descriptive research design. For this investigation, the target population was composed of respondents from G4S Kenya Limited which takes pride in having more than 1500 representatives split into top-level. In this investigation, the stratified sampling research design method was applied. The researcher picked who, as they would see it, is believed to be significant to the research theme. For this situation, the judgment of the researcher was regarded as being more fundamental as compared to acquiring a likelihood test. The way toward testing, for this situation, included the identification of the respondents from their particular administration levels. Researchers don't concede to the correct extent of the available population that should frame the sample measurement. Bryman and Bell, (2015) propose that in enlightening examinations $(10 \%)$ of the total population is representative enough, to sum up qualities being watched. The researcher utilized $10 \%$ of the aggregate population which consisted of 
150 workers with the end goal of the investigation and was resolved by the level of precision and certainty level required from the chosen populace under examination.

Questionnaires were the principal instrument of information gathering. Both structured and unstructured questions were availed for the examination to gather essential information. Information gathered was evaluated with the aid of descriptive statistics using the Statistical Package for Social Sciences (SPSS) and Microsoft office excel. Detailed statistical science encompassed the procedure of converting accumulated raw data into tables and charts with frequency distribution and percentages which were key in interpretation. The investigation made use of frequencies, percentages, and statistical mean. To establish the impact of each independent variable on the dependent variable, a regression model was utilized to assist in evaluating and describing the relationship between various variables. ANOVA which stands for analysis of variance was applied in testing the gravity of the model. The degree of excellence of suitability of the regression model will be evaluated by the application of R2 in this investigation.

\section{DATA ANALYSIS RESULTS}

The correlation outcome in table 1 reveals that systems thinking and organization performance are positively related $(\mathrm{r}=.230, \mathrm{p}=.00)$; personal mystery and performance are positively related $(\mathrm{r}=.144, \mathrm{p}=.019)$; mental models and performance are positively related $(\mathrm{r}=.689, \mathrm{p}=.000)$; and last but not least, shared vision and performance are positively related $(\mathrm{r}=.278, \mathrm{p}=.000)$ The outcome implies that system thinking, personal mastery, mental models and shared vision can potentially influence the organization performance at G4S Kenya.

Table 1: Correlation analysis

Systems Personal Mental Shared Performance

\begin{tabular}{llll}
$\mathrm{T}$ & $\mathrm{M}$ & $\mathrm{M}$ & $\mathrm{V}$ \\
\hline
\end{tabular}

\begin{tabular}{lllllll} 
Systems T & Pearson & 1 & -.033 & $-.203^{* *}$ & -.075 & $.230^{* *}$ \\
& Correlation & & & & & \\
Personal M & Sig. (2-tailed) & & .591 & .001 & .224 & .000 \\
& $\begin{array}{l}\text { Pearson } \\
\text { Correlation }\end{array}$ & -.033 & 1 & -.067 & -.025 & $.144^{*}$ \\
& Sig. (2-tailed) & .591 & & & & \\
Mental M & Pearson & $-.203^{* *}$ & -.067 & 1 & .085 & .019 \\
& Correlation & & & & $.330^{* *}$ & $.689^{* *}$ \\
& Sig. (2-tailed) & .001 & .277 & & .000 & .000 \\
Shared V & $\begin{array}{l}\text { Pearson } \\
\text { Correlation }\end{array}$ & -.075 & -.025 & $.330^{* *}$ & 1 & $.278^{* *}$ \\
& Sig. (2-tailed) & .224 & .685 & .000 & & .000 \\
Performance & $\begin{array}{l}\text { Pearson } \\
\text { Correlation }\end{array}$ & $-.230^{* *}$ & $.144^{*}$ & $.689^{* *}$ & $.278^{* *}$ & 1 \\
& Sig. (2-tailed) & .000 & .019 & .000 & .000 & \\
\hline
\end{tabular}

**. Correlation is significant at the 0.01 level (2-tailed). *. Correlation is significant at the 0.05 level (2-tailed). 
The model summary result shows that $\mathrm{R}=.588$, this denotes that the four predictive variables, moderately correlate with organization performance. The coefficient of determination; $\mathrm{R}$ square is .345 ; this denotes that the three predictors jointly provided likely explanation for $34 \%$ of the deviations in the organization. The rest of the percentage provides likely explanation for variables other than the ones in the model.

Table 2: Model Summary

\begin{tabular}{lllll}
\hline Model & $\mathrm{R}$ & R Square & Adjusted R Square & Std. Error of the Estimate \\
\hline 1 & $.588^{\mathrm{a}}$ & .345 & .335 & .656 \\
\hline
\end{tabular}

a. Predictors: (Constant), Systems T, Personal M, Mental M, Shared V

The outcome in Table 3 denotes the regression coefficients of the three independent variables (and the constant). The regression model of Performance $=2.374+.444$ System $\mathrm{T}+$ .101 Personal $\mathrm{M}+.612$ Mental $\mathrm{M}+.104$ Shared V

Table 3: Regression Coefficient

\begin{tabular}{lllllll}
\hline Model & \multicolumn{2}{l}{ Unstandardized Coefficients } & $\begin{array}{l}\text { Standardized } \\
\text { Coefficients } \\
\text { Beta }\end{array}$ & $\mathrm{t}$ & & Sig. \\
& $\mathrm{B}$ & Std. Error & .373 & & 6.368 & .000 \\
\hline 1 & (Constant) & 2.374 & .067 & .375 & 6.586 & .000 \\
& System T & .444 & .044 & .129 & 2.324 & .021 \\
& Personal M & .101 & .181 & .182 & 3.389 & .001 \\
& Mental M & .612 & .036 & .153 & 2.906 & .004 \\
\hline
\end{tabular}

a. Dependent Variable: organization performance

The outcome indicates that systems thinking has a positive significant influence on organization performance $(\beta=.444, p=.000)$, personal mastery has a significant positive influence on organization performance $(\beta=.101, \mathrm{p}=.000)$, mental models positively and significantly influence organization performance $(\beta=.612, p=.000)$. Shared vision has a significant influence on organization performance $(\beta=.104, p=.000)$.

\section{CONCLUSIONS}

The outcomes of this research indicated that system thinking provides continuous learning opportunities in the organization; embraces creative tension as a source of energy and renewal, link individual performance with organizational performance, enhances organization performance, uses learning to reach goals not to mention improve customer service. This is so following a greater proportion of the respondents who indicated that system thinking link individual performance with organizational performance. This element was recorded notably on the adjusted Likert scale thus an evident sign of the significance of system thinking on the performance of G4S Kenya Limited. The researcher discovered that personal mastery helps employees in setting specific goals and objectives in the organization this owing to the conviction that an immense collection of the respondents agreed with the statement. A substantial count of respondents believed that personal mastery helps in resolving the creative 
tension in the organization while others indicated that personal mastery helps employees to challenge the way they perceive the world and others. Apart from leading to organization profitability, the researcher also discovered that personal mastery promotes safety and improve working conditions in addition to maintaining or improving product quality.

From the findings, the researcher found out that mental model helps in surfacing deep-seated beliefs as well as encourage people to reframe. Some respondents indicated that mental models promote inquiry and trust while other respondents indicated that mental models help in eliminating unwanted values. On inquiring if mental models preserve certain behaviors, the respondents strongly agreed to the statement with a considerable percent. Concerning the effect of shared vision on improving organization performance, 58\% of the respondents supported the statement. Other respondents indicated that shared vision enable people to excel and learn in their day today life, others indicated that shared vision develops efficient and effective operation at workplace while some indicated that shared vision enhance proper management of resources. The researcher also realized that shared vision improves reliability and customer service

\section{RECOMMENDATION}

The study confirmed that learning organization has a significant influence on organization performance at G4S Kenya Limited. Strategic executives could possibly use findings of this investigation to support the need for implementation of learning organization initiatives. Policymakers could apply the findings of study to reinforce numerous areas of strategic management practice and policy in their organizations. Need assessment can be done, and programs designed that effectively address any performance gaps. Key areas to be addressed include learning organization practices such as continuous learning, team learning, empowerment and, systems connectivity. In addition, policymakers can use the findings of this study to evaluate how well the organizations can be leveraged through learning organization practices in order to contribute to the increased economic growth.

\section{REFERENCES}

Adler, F. et al. (2016). The value concept in sociology. American Journal of Sociology, $62,272-279$

Argyris, C. (2014). Behind the front page. San Francisco: Jossey Bass, USA.

Argyris, C. (2016). Increasing leadership effectiveness. New York: Wiley-Interscience.

Argyris, C. (2010). Inner contradictions of rigorous research. New York: Academic Press.

Argyris, C. (2012). Reasoning, learning, and action: Individual and organizational. San Francisco: Jossey Bass, USA.

Argyris, C. (2015). Strategy, change \& defensive routines. Boston: Pitman, United States of America.

Argyris, C. (2015). Reasoning, action strategies, and defensive routines: The case of OD practitioners, in Woodman, R. A. \& Passmore, A.A. (Eds), Research in organizational change and development. Vol 1 p89-128. Greenwich: JAI Press.

Argyris, C., \& Schon, D. (2014). Theory in practice: Increasing professional effectiveness. San Francisco: Jossey Bass, United States of America.

Argyris, C., \& Schon, D. (2015). Organizational learning: A theory of action perspective. Reading, Mass: Addison Wesley.

Bales, R.F., \& Couch, A. (2014). The value profile: A factor-analytic study of value statements. Sociological Inquiry, 39, 3-17

Ballard, G.; Grémillet, D.; Authier, M.; Ainley, D. G. (2014). Business Research Methods

Descamps, Sebastian, Ed. PLoS ONE $9 \quad$ (1): e85291. 
Blake, R.R., Mouton, J.S., \& McCanse, A.A. (2016). Change by design. Mass: AddisonWesley, USA.

Baumeister, R. (2012). A self-presentational view of social phenomena. Psychological Bulletin, 91, 3-26.

Bontis, N. and Serenko, A. (2009). "A follow-up ranking of academic journals," Journal of Knowledge Management, Vol. 13 No. 1.

Brickman, P. (2012). Rational and non-rational elements in reactions to disconfirmation of performance expectancies. Journal of Experimental Social Psychology, 8, 112-123.

Bryman, A., \& Bell, E. (2015). Business Research Methods. London: Oxford University Press.

Carey, A., \& Varney, G.H. (2015). Which skills spell success in O.D.? Training and Development Journal, April.

Carnall, C.A. (2010). Managing change in organizations. Prentice Hall, New York, USA.

French, A.L., \& Bell, C.H., (2014). Organization development: Behavioural science interventions for organization improvement, 3rd Ed. New Jersey: Prentice-Hall.

Fossum, L. (2016). Understanding organizational change. Los Altos, Ca. Addison- Wesley.

Garvin, David. Jan. (2014). Building a Learning Organization. Business Credit, Vol. 96, No. 1, pp. 19-28.

Gerger, K. (2014). Towards a psychology of receiving help. Journal of Applied Social Psychology, 4, 184-193.

Gephart, Martha A., Victoria J. Marsick, Mark E. Van Buren, and Michelle S. Spiro.Dec. (2016).Learning Organizations Come Alive. Training \& Development, Vol. 50, No. 12 , pp. 35-45.

Howe, R.J., Howe, M., \& Mindell, M. (2012). Management values inventory. San Diego: University Associates.

Johnson, Kenneth W. (2013). The Learning Organization: What is It? Why Become One? Navran Associates' Newsletter.

Kaplan, Robert S., and David P. Norton. Sept./Oct. (2016). Strategic Planning and the Balanced Scorecard. Strategy \& Leadership, Vol. 24, No. 5, pp. 18-24.

Kelly, G.A., (2013). A theory of personality: The psychology of personal constructs. New York: Norton.

Larson, J.R. (2016). The dynamic interplay between employees' feedback-seeking strategies and supervisors' delivery of performance feedback. Academy of Management Review, 14 (3), 408-422.

Levy, A. (2016). Second order change: Definition and conceptualization. Organisation Dynamics, Summer 5 - 20.

Liker, J.K. and Trachilis, G. (2014). Developing Lean Leaders at All Levels: A Practical Guide. Lean Leadership Institute Publications, Cambridge.

Lorsch, J. (2015). Managing culture: The invisible barrier to strategic change. California Management Review, 28(2), 95-109.

Mahapatro, B. B. (2010). New age human resource management. E-book.New Delhi: New Age International (P) Ltd.

Mathews, J. (2012). Tools of change; New technology and the democratization of work. Sydney: Pluto Press.

Marah F. Abu Khadra, Ibrahim A. Rawabdeh, (2016) "Assessment of development of the learning organization concept in Jordanian industrial companies, " The Learning

Organization, Vol. 13 Issue: 5, pp.455-474.

Muhia, J.K., (2014). Change Management Practices Adopted at the City Council of Nairobi. Unpublished MBA Project. School of Business, University of Nairobi. 
Mute, T.M., (2016) Change Management and Competitive advantage at Nairobi Water and Sewerage Company, Unpublished MBA project. School of Business, University of Nairobi.

Napier, R.W. \& Gershenfeld, M.K. et al., (2015). Groups: Theory and experience, (4th ed.). Boston: Houghton Mifflin Company.

Oganda A., (2017) Strategic and Change Management at Plan International Inc-Kenya, Unpublished MBA Project, School of Business University of Nairobi.

Rheem, Helen. Mar./Apr. (2015). The Learning Organization. Harvard Business Review, Vol. 73, No. 2, p. 10.

Senge, Peter. (2010). The Fifth Discipline: the Art and Practice of the Learning Organization. New York: Doubleday.

Senge, Peter (2016). Leading Learning Organizations. Training \& Development, Vol. 50, No. 12, pp. 36-4.

Schein, E.H. (2012). Process consultation. Reading, Mass: Addison-Wesley.

Schon, D. (2013). The reflective practitioner. New York: Basic Books.

Schutz, W. (2016). The interpersonal underworld. California: Science and Behavior Books.

Smith, M.B. (2012). Psychology and values. Journal of Social Issues, 34(4), 181-199.

Swann, W.B., Jr. (2013). Self-verification: Bringing social reality into harmony with the self. In J. Suls \& A.G. Greenwald (Eds.), Psychological perspectives on the self. New Jersey: Erlbaum.

Swann, W.B., Jr. et al., (2015). The self as the architect of social reality. In B.R. Schlenker (ed.), the self and social life. New York: McGraw-Hill.

Swann, W.B., Jr. (2012). Identity negotiation: Where two roads meet. Journal of Personality and Social Psychology, 53, 1038-1051.

Thai, K. V. (2001). Business Research Methods. Quantitative and Mixed Methods Approaches. 4th Edition, New Delhi, New Age International.

Tichy, N.M., \& Nisberg J.N. (2016). Change agent bias: What they view determines what they do. Group and Organisation Studies, 1(3), 286-301.

Tuckman, B.W. (2015). Developmental sequence in small groups. Psychological Bulletin, 6396, 384-399.

Watzlawick, P., Weakland, J., \& Fisch, R. (2014). Change: principles, problem formulation, and problem resolution. New York: Norton.

Wolpe, J. (2015). Psychotherapy by reciprocal inhibition. Stanford: Stanford University Press.

Woodward, H., \& Buchholz, S. (2013). Aftershock: Helping people through corporate change. New York: Wiley \& Sons.

Zuber-Skerrit, O. (2010). Action research for change and development. Brisbane: C.A.L.T., Griffith University.

Zuber-Skerritt, (2012). "From learning organization to learning community: Sustainability through lifelong learning", The Learning Organization, Vol. 19 Issue: 5, pp.400-413.

This is an open-access article published and distributed under the terms and conditions of the $(\mathrm{cc}) \mathrm{EY}$ Creative Commons Attribution 4.0 International License of United States unless otherwise stated. Access, citation and distribution of this article is allowed with full recognition of the authors and the source.

Authors seeking to publish with an International Peer Reviewed Journal should consider www.ijcab.org by writing to the Editor at editor@ijcab.org. The articles must be quality, value adding and meet originality test. 